\title{
Cytogenotoxicity of Abattoir Effluent in Clarias gariepinus (Burchell, 1822) Using Micronucleus Test
}

\author{
Chibuisi G. Alimba, ${ }^{1}$ Ebenezer O. Ajayi, ${ }^{2}$ Titilayo Hassan, ${ }^{2}$ \\ Akindayo A. Sowunmi, ${ }^{3}$ and Adekunle A. Bakare ${ }^{1}$ \\ ${ }^{1}$ Cell Biology and Genetics Unit, Department of Zoology, University of Ibadan, Ibadan 200005, Nigeria \\ ${ }^{2}$ Ecology and Environmental Biology Unit, Department of Zoology, University of Ibadan, Ibadan 200005, Nigeria \\ ${ }^{3}$ Hydrobiology and Fisheries Unit, Department of Zoology, University of Ibadan, Ibadan 200005, Nigeria \\ Correspondence should be addressed to Adekunle A. Bakare; adebakar19@yahoo.com
}

Received 13 August 2015; Accepted 19 October 2015

Academic Editor: Hong Feng

Copyright (C) 2015 Chibuisi G. Alimba et al. This is an open access article distributed under the Creative Commons Attribution License, which permits unrestricted use, distribution, and reproduction in any medium, provided the original work is properly cited.

The cytogenotoxic potential of abattoir effluent from Bodija, Nigeria, was investigated using micronucleus test in Clarias gariepinus. Fish was exposed to five different concentrations: $0.2,0.4,0.8,1.6$, and $3.1 \%$ of the effluent for 7,14 , and 28 days. Tap water and $0.02 \mathrm{~mL} / \mathrm{L}$ of benzene were used as negative and positive controls, respectively. Physicochemical parameters and heavy metals were analyzed in the effluent in accordance with standard methods. After exposure, blood was collected from the treated and control fish and slides were prepared for micronuclei $(\mathrm{MN})$ and nuclear abnormality evaluation in the peripheral erythrocytes. The effluent induced significant $(p<0.05)$ increase in the frequency of MN in a time dependent manner. Similarly, the frequency of total nuclear abnormalities (blebbing, notch, bud, binucleation, and vacuolation) was higher in the exposed fish than the negative control. Electrical conductivity, nitrate, biochemical oxygen demand, chemical oxygen demand, arsenic, and copper analyzed in the effluent may have provoked the observed cytogenetic damage. The findings herein suggest the presence of clastogens and cytotoxins in Bodija abattoir wastewater which are capable of increasing genomic instability in aquatic biota.

\section{Introduction}

Pollution of the aquatic ecosystems by incidental and deliberate discharge of xenobiotics is increasing at alarming rate worldwide. This is linked mainly to unprecedented human population growth which accounts for the increasing anthropogenic activities. For instance, increasing meat production to meet the protein needs of human population has contributed greatly to the pollution status of aquatic ecosystems [1]. Abattoirs, places where animals are slaughtered for meat collection, generate large amount of solid wastes and effluents containing rumen contents, blood, and large volume of wash water. Considering that animal slaughtering operations require large volume of water, most private and government owned abattoirs in Nigeria are sited close to rivers or water sources to enable proper washing of the meat after slaughtering [2]. This undoubtedly results in disposing of abattoir effluents and solid wastes directly into streams and rivers without treatment [1]. This act increases problems related to obnoxious odour of the water bodies and land, proliferations of flies (vectors of human and animal diseases), and surface and ground water contamination with pathogens and undesirable toxic metals and organic chemicals. There is increasing global concern due to possible health impacts on the biota and environmental degradation that may result from xenobiotics in abattoir solid wastes and effluent [2].

Studies have shown that abattoir solid wastes and effluents contaminated rivers contain high concentrations of hazardous trace metals such as $\mathrm{Zn}, \mathrm{Cu}, \mathrm{Cr}, \mathrm{Fe}, \mathrm{Cd}$, and $\mathrm{Pb}[1,3,4]$ and high microbial loads $[1,2]$. However, studies assessing the genotoxicity and cytotoxicity of abattoir effluents using micronucleus test in aquatic vertebrates are relatively scarce. There is need to investigate the possible cytogenotoxic effects of abattoir effluents in fish, in order to protect aquatic biota from predisposition to genetic related abnormalities and biodiversity loss. The use of genetic biomarkers in the 
routine monitoring of industrial and agricultural effluents for the presence of xenobiotics that are capable of eliciting DNA damage in aquatic biota will enhance the survival through prompt reproduction of the aquatic forms and reduce pollutant-induced stress syndromes $[5,6]$.

Clarias gariepinus (African catfish) is a benthopelagic fresh water fish, with feeding habits and ecological distribution that increases its exposure to xenobiotics [7]. Its use in previous studies to assess the cytogenotoxic effects of municipal landfill leachate [8], e-waste leachates, and e-waste contaminated underground water [9] and textile effluent [10] using micronucleus test suggests its sensitivity to detecting the DNA damaging effects induced by mixture of xenobiotics in the effluents. The ease to culture C. gariepinus due to rapid turnover rate and high adaptation to varying laboratory conditions accounts for its use in scientific studies and as the most locally consumed African clarrid in Nigeria. In this study, we investigated the genotoxic and cytotoxic potentials of abattoir effluent in C. gariepinus using micronucleus test. Some physicochemical parameters and heavy metals were also analyzed in the effluent.

\section{Materials and Methods}

2.1. Sampling Site. Bodija abattoir (longitude $7^{\circ} 25^{\prime} 35^{\prime \prime} \mathrm{N}$ and latitude $\left.3^{\circ} 54^{\prime} 39^{\prime \prime} \mathrm{E}\right)$, located in Ibadan, Oyo State in Nigeria, is the major recipient of bovine and swine from different parts of the country. The abattoir is an open slaughtering slab for daily killing of 300-350 cattle heads, 150-200 sheep and goats, and 50-100 pigs by dehairing with hot water and/or burning using fire [3]. The butchering of the slaughtered animals and washing of the guts and meat release large volume of wastewater into Alamuyo River (about $500 \mathrm{~m}$ from the slaughter house) [11].

2.2. Wastewater Sampling, Heavy Metals, and Physicochemical Analysis. Abattoir effluent collected from Bodija abattoir at different discharge points was filtered to remove debris and mixed to obtain a composite sample. The physical and chemical parameters of the effluent, dissolved oxygen (DO), biochemical oxygen demand (BOD), chemical oxygen demand (COD), total solids (TS), chloride, $\mathrm{pH}$, acidity, alkalinity, electrical conductivity, phosphate, and nitrate, were measured in accordance with APHA [12]. The concentrations of arsenic (As), lead $(\mathrm{Pb})$, copper $(\mathrm{Cu})$, cadmium $(\mathrm{Cd})$, nickel $(\mathrm{Ni})$, and chromium $(\mathrm{Cr})$ were determined according to APHA [12] and USEPA [13] using PerkinElmer A3100 atomic absorption spectrophotometer.

2.3. Animal and Experimental Design. Juvenile C. gariepinus (mean \pm SD body weight $6.60 \pm 2.40 \mathrm{~g}$ and length $8.30 \pm$ $1.00 \mathrm{~cm}$ ) obtained from the Fisheries Department, Oyo State Ministry of Agriculture and Natural Resources, Ibadan, were used for the study. They were acclimated to laboratory conditions of $26^{\circ} \mathrm{C}$ and $12 / 12 \mathrm{~h}$ dark/light modes for not less than 14 days prior to the experimental set-up. They were stocked at a population density of 15 fish per $25 \mathrm{~L}$ transparent plastic aquarium containing dechlorinated water and fed 5\% of their body weight with standard fish feed which contains $35 \%$ crude protein twice daily.

$0.20,0.40,0.80,1.60$, and $3.14 \%$ (v/v; effluent/dechlorinated tap water) concentrations of the effluent corresponding to $1 / 32,1 / 16,1 / 8,1 / 4$, and $1 / 2$, respectively, of the $96 \mathrm{hr}$ $\mathrm{LC}_{50}$ of $6.28 \%$ [14] were selected for the sublethal toxicity study. C. gariepinus were exposed to the different effluent concentrations by immersion for 7, 14, and 28 days, and five fish were analyzed at each sampling time from each concentration of the effluent sample. Similar treatments were given to fish exposed to dechlorinated tap water and $0.02 \mathrm{~mL} / \mathrm{L}$ of benzene (Sigma, St. Louis, MO, Australia) as negative and positive controls, respectively. The test effluents and control substances were replaced every $48 \mathrm{~h}$ to reduce accumulation of metabolic wastes, remains of food particles, and volatilization of less stable substances in the effluent and benzene.

2.4. Micronucleus Analysis. At the end of each exposure time, blood was collected from the caudal vein of each fish in a test group and control groups for $\mathrm{MN}$ analysis. Thin smear of the peripheral blood was made on three precleaned slides per fish. The slides were air dried, fixed in absolute methanol for 30 minutes, and counterstained with 10\% May-Grunwald and $5 \%$ Giemsa $[8,15] .3000$ erythrocytes per fish were scored for micronucleus induction at $\times 1000$. Nuclear abnormalities (NAs) were also scored as cytotoxic parameters $[9,16]$ at the same magnification. Cells with two nuclei were considered as binucleated $(\mathrm{BN})$. Blebbed nucleus $(\mathrm{BL})$ presents a relatively small evagination of the nuclear membrane, which contains euchromatin. When the evagination is larger than the blebbed nuclei and containing several lobes, it was considered as lobe nucleus (LB), while notched nucleus (NT) contains vacuoles and appreciable depth into the nucleus that does not contain nuclear materials. Other scored NAs are budding nucleus. Only cells with intact cell and nuclear membranes were scored.

2.5. Statistical Analysis. All statistical analyses were conducted using Graphpad prism 5.0 computer programs. Data are presented as mean \pm standard error (SE). One-way analysis of variance (ANOVA) was used to determine the differences among various groups, while Dunnett multiple post hoc test was used to compare the level of significance $(p<0.05)$ of each treated group with the negative control.

\section{Results}

The physicochemical parameters and heavy metals analyzed in the abattoir effluent are presented in Table 1. $\mathrm{pH}$, alkalinity, electrical conductivity, nitrate, TS, BOD, COD, and As and $\mathrm{Cu}$ concentrations were higher than respective values in the negative control and national and international allowable limits for effluent quality criteria standards. $\mathrm{Pb}, \mathrm{Cd}, \mathrm{Ni}$, and $\mathrm{Cr}$ were below detectable limit, while chloride, DO, and phosphate were below permissible limits by NESREA (Nigeria) and USEPA (USA) standards. 
TABLE 1: Physicochemical parameters and heavy metals analyzed in the abattoir effluent and tap water.

\begin{tabular}{lcccc}
\hline Parameters & Effluent & Tap water & NESREA $^{\mathrm{a}}$ & USEPA $^{\mathrm{b}}$ \\
\hline $\mathrm{pH}$ & 8.93 & 8.20 & $6.5-8.5$ & $6.5-8.5$ \\
Acidity & 7500.02 & 1.51 & - & - \\
Alkalinity & 250.09 & 3.06 & - & 20 \\
EC $^{\mathrm{c}}$ & 850 & 44 & - & - \\
Phosphate & 2.12 & 0.20 & 3.5 & 5 \\
Nitrate & 586.2 & 0.18 & 9.1 & 10 \\
TS $^{\mathrm{d}}$ & 8876 & 98.4 & - & - \\
DO $^{\mathrm{e}}$ & 2.1 & 7.7 & - & - \\
BOD $^{\mathrm{f}}$ & 582.6 & 0.78 & 3 & 250 \\
COD $^{\mathrm{g}}$ & 728.3 & 1.69 & 30 & 410 \\
Chloride & 13.5 & 56.7 & 300 & 250 \\
Arsenic & 0.68 & 0.004 & 0.05 & - \\
Lead & $\mathrm{BDL}$ & $\mathrm{BDL}$ & 0.01 & 0.015 \\
Copper & 0.10 & 0.05 & 0.001 & 1.3 \\
Cadmium & $\mathrm{BDL}$ & $\mathrm{BDL}$ & 0.005 & 0.005 \\
Nickel & $\mathrm{BDL}$ & $\mathrm{BDL}$ & 0.01 & - \\
Chromium & $\mathrm{BDL}$ & $\mathrm{BDL}$ & 0.01 & 0.1 \\
\hline
\end{tabular}

All values are in $\mathrm{mg} / \mathrm{L}$ except $\mathrm{pH}$, alkalinity, acidity, and $\mathrm{EC}(\mu \mathrm{S} / \mathrm{cm}) . \mathrm{BDL}$, below detectable limit.

${ }^{a}$ NESREA: National Environmental Standards and Regulations Enforcement Agency (2011) (Nigeria) maximum permissible limits for effluent for fisheries and recreational quality criteria standards.

${ }^{b}$ USEPA: United States Environmental Protection Agency (2006) (http://www.epa.gov/safewater/mcl.html).

${ }^{c}$ Electrical conductivity; ${ }^{d}$ total solid; ${ }^{e}$ DO: dissolved solid; ${ }^{f}$ biochemical oxygen demand.

${ }^{g}$ Chemical oxygen demand.

The abattoir effluent induced significant increase in percentage frequency of micronucleated erythrocytes in peripheral blood of C. gariepinus at the different exposure durations (Figure 1). The induced $\mathrm{MN}$ in the effluent treated C. gariepinus was higher than the tap water cultured fish by 4.05-, 4.03-, 4.55-, 3.53-, and 14.65-fold for 7 days' exposure; 10.84-, 6.17-, 15.50-, 9.17-, and 6.50-fold for 14 days' exposure; and 28.55-, 25.06-, 29.83-, 25.56-, and 26.08-fold for the 28 days' exposure according to $0.20,0.40,0.80,1.60$, and $3.14 \%$ effluent concentrations, respectively. $\mathrm{MN}$ induction did not show concentration dependent increase according to the effluent concentrations but increased according to exposure duration. Table 2 showed concentration independent significant increase in percentage frequency of total nuclear abnormalities in peripheral erythrocytes of C. gariepinus. The nuclear abnormalities decreased with increasing exposure time. Figure 2 presents the photomicrographs of the various micronucleated and nuclear abnormalities scored in the peripheral erythrocytes of C. gariepinus.

\section{Discussion}

Pollution of most aquatic and terrestrial ecosystems due to abattoir effluent discharge is eliciting national and international response due to the release of emergent xenobiotics into the environment $[17,18]$. Chemical and microbial

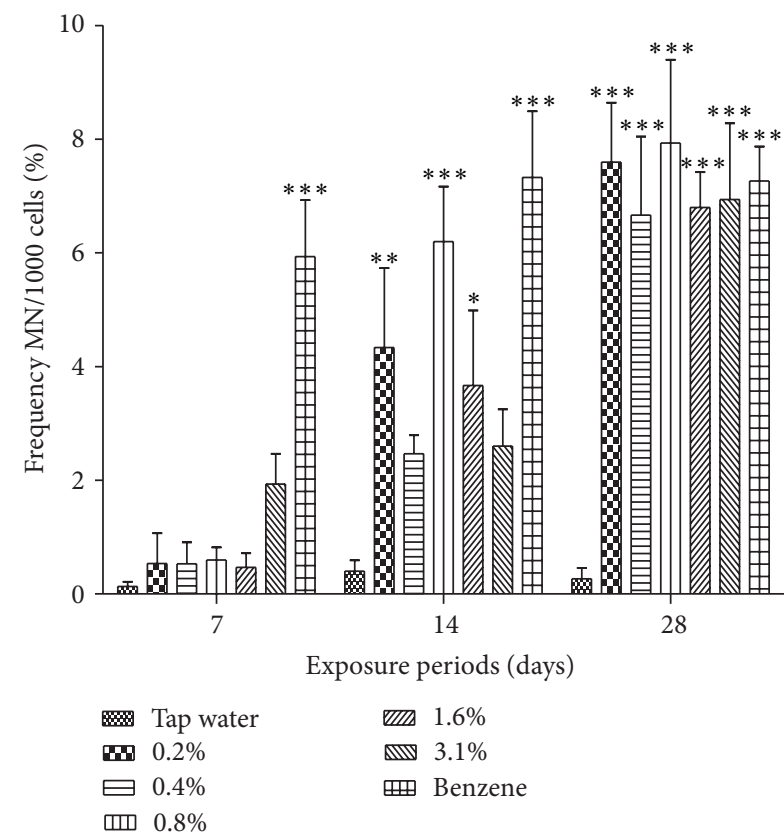

FIgURE 1: Percentage frequency of micronucleus formation in peripheral erythrocytes of $C$. gariepinus exposed to abattoir effluent. ${ }^{*} p<0.05 ;{ }^{* *} p<0.01 ;{ }^{* * *} p<0.001$ which are significantly different from corresponding negative controls (tap water) using Dunnett's multiple post hoc comparison test. Benzene $(0.02 \mathrm{~mL} / \mathrm{L})$ positive control.

constituents of most abattoir effluents are known mutagens and carcinogens that are capable of increasing DNA damage in most biota [19]. The cytogenotoxicity induced by the abattoir effluent in C. gariepinus, vis-à-vis increased micronucleus and nuclear abnormalities in peripheral erythrocytes, suggests that xenobiotics, mostly toxic metals and organic compounds, in the tested effluent are clastogens and/or aneugens. The observed micronucleus and nuclear abnormalities indicate increased genetic alterations which may enhance somatic mutation and cancer formation [20]. This may lead to decreased embryonic viability, genetic disorders, reduced fitness, and biodiversity loss in aquatic biota [21].

Studies are scarce on the cytotoxicity and genotoxicity of abattoir effluents in both terrestrial and aquatic organisms, but there are similar observations as obtained herein with other wastewater/effluents from Nigeria [8-10]. Arsenate observed at higher concentrations in the tested abattoir effluent has been reported to possess clastogenic and aneugenic properties which may increase genomic instability enhancing mutagenesis and carcinogenesis in biological systems [22, 23]. Its genotoxic effect was linked to oxidative DNA adducts and DNA-protein cross-links [24]. Also Cu observed in the effluent though is considered an essential element that plays vital roles in normal enzyme activities but may induce DNA damage at higher concentration by binding to biologically sensitive molecules and forming dangerous free radicals [25-27]. Higher concentration of nitrate in the effluent is attributed to the evisceration and slaughter processes which release undigested stomach content into the wastewater [3, 
TABLE 2: Mean \pm SE/1000 cells of total nuclear abnormalities (NA) in peripheral erythrocytes of C. gariepinus exposed to abattoir effluent.

\begin{tabular}{lcccc}
\hline Treatment & Conc. $(\mathrm{v} / \mathrm{v} ; \%)$ & 7 days & 14 days & 28 days \\
\hline Tap water & 0 & $0.01 \pm 0.08$ & $0.01 \pm 0.01$ & $0.00 \pm 0.00$ \\
Benzene & $0.02(\mathrm{~mL} / \mathrm{L})$ & $0.19 \pm 0.0^{\mathrm{a}}$ & $0.32 \pm 0.10^{\mathrm{a}}$ & $0.22 \pm 0.16^{\mathrm{a}}$ \\
& 0.2 & $0.19 \pm 0.11^{\mathrm{a}}$ & $0.03 \pm 0.12$ & $0.10 \pm 0.04^{\mathrm{a}}$ \\
Abattoir & 0.4 & $0.61 \pm 0.29^{\mathrm{c}}$ & $0.21 \pm 0.10^{\mathrm{a}}$ & $0.28 \pm 0.12^{\mathrm{a}}$ \\
effluent & 0.8 & $0.91 \pm 0.25^{\mathrm{c}}$ & $0.14 \pm 0.04^{\mathrm{a}}$ & $0.29 \pm 0.16^{\mathrm{a}}$ \\
& 1.6 & $0.64 \pm 0.27^{\mathrm{c}}$ & $0.08 \pm 0.03$ & $0.28 \pm 0.09^{\mathrm{a}}$ \\
& 3.1 & $0.25 \pm 0.08^{\mathrm{a}}$ & $0.08 \pm 0.05$ & $0.22 \pm 0.12^{\mathrm{a}}$ \\
\hline
\end{tabular}

Superscripts are significantly $\left({ }^{\mathrm{a}} p<0.05 ;{ }^{\mathrm{c}} p<0.001\right)$ different from negative control using Dunnett's multiple post hoc comparison test.

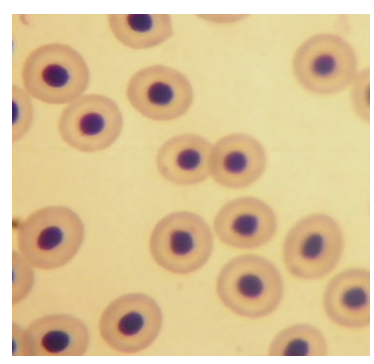

(a)

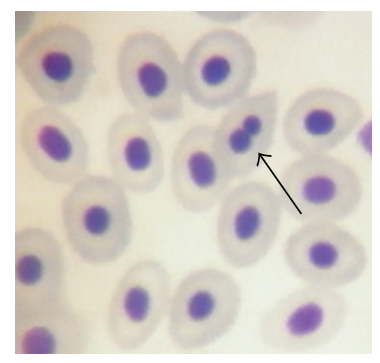

(e)

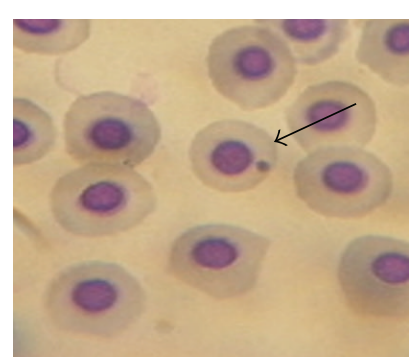

(b)

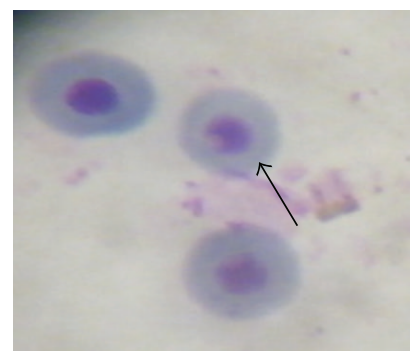

(f)

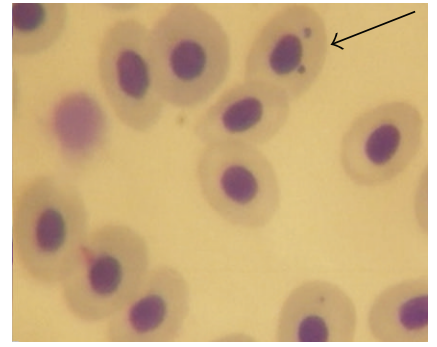

(c)

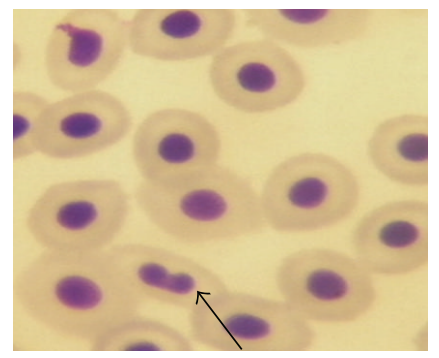

(g)

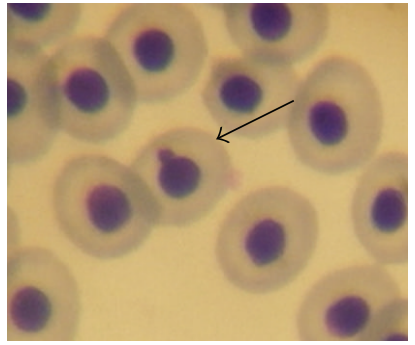

(d)

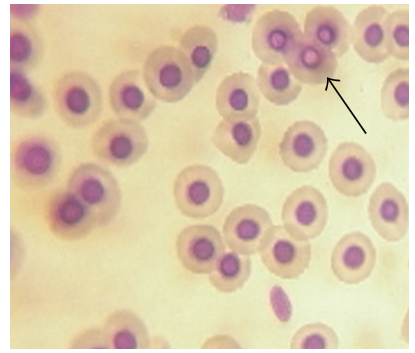

(h)

Figure 2: Micronucleated (MN) and nuclear abnormalities observed in abattoir effluent treated C. gariepinus are shown by the arrows: (a) normal peripheral erythrocyte. (b) MN peripheral erythrocyte. (c) Bi-MN peripheral erythrocyte. (d) Budded nucleus. (e) Binucleated peripheral erythrocyte. (f) Peripheral erythrocytes with notched nucleus. (g) Binucleated peripheral erythrocyte. (h) Vacuolated nucleus in peripheral erythrocytes.

28]. It is plausible that high nitrogenous compounds in the effluent formed reactive free nitric acid (NO), a cytotoxin, with mutagenic and carcinogenic properties, which increased the induction of micronucleated erythrocytes in the treated C. gariepinus [29]. The dose and time dependent variations in $\mathrm{MN}$ and NAs formation are in accordance with Hooftman and de Raat [30], who reported similar trend in eastern mud minnow, Umbra pygmaea, when exposed to ethyl methanesulfonate.

Nuclear abnormality assessment along with MN during cytotoxicity and genotoxicity monitoring of xenobiotics is efficient in fresh water fishes and under laboratory controlled conditions. Significant increase in total nuclear abnormalities observed in the treated C. gariepinus compared to the control suggests the presence of cytotoxins in the effluent. Their formations are linked to xenobiotic interference with the cell cycle and DNA synthesis via various mechanisms [31]. The formation of binucleated cells suggests that constituents of the effluent are capable of blocking cytokinesis of a normal dividing cell at $\mathrm{M}$ phase of the cell cycle [32] and may increase mutational frequency and carcinogenesis [33]. The presence of notch and bleb nuclei is associated with chromosome aneuploidy due to disturbance of the chromatin materials by xenobiotics in the abattoir effluent [32]. Vacuolated cell and nuclear bud formation (Figure 2) are associated with cell injury, cell death, and apoptosis induced by xenobiotics in the effluent [34].

High concentrations of electrical conductivity, TS, phosphates, nitrates, BOD, and COD and low concentration of DO in the abattoir effluent are in concert with those reported from Ogun River, Nigeria, which also received untreated abattoir effluent from slaughter houses [35]. These parameters along with heavy metals and unanalyzed organic compounds contributed to the induction of MN and NAs in peripheral erythrocytes and gill erythrocytes of Synodontis clarias, in the river [36]. This suggests threats to the functioning of the 
aquatic ecosystems and the survival of most aquatic biota in abattoir wastewater polluted water bodies.

\section{Conclusion}

Clarias gariepinus were exposed to different concentrations of abattoir effluents from Bodija slaughtered house in Ibadan, Nigeria. The high concentration of the physicochemical parameters and some toxic heavy metals in the abattoir effluent provoked DNA damage via elevated micronucleated erythrocytes and erythrocytes with nuclei abnormalities in C. gariepinus. Xenobiotics in abattoir effluents are emerging clastogens and/or aneugens that are capable of inducing cytotoxicity and genotoxicity in aquatic biota.

\section{Conflict of Interests}

The authors declare no conflict of interests.

\section{References}

[1] E. I. Atuanya, N. A. Nwogu, and E. A. Akpo, "Effluent qualities of government and private abattoirs and their effects on Ikpoba River, Benin city, Edo state, Nigeria," Advances in Biological Research, vol. 6, no. 5, pp. 196-201, 2012.

[2] A. O. Adesemoye, B. O. Opere, and S. C. O. Makinde, "Microbial content of abattoir wastewater and its contaminated soil in Lagos, Nigeria," African Journal of Biotechnology, vol. 5, no. 20, pp. 1963-1968, 2006.

[3] O. Osibanjo and G. U. Adie, "Impact of effluent from Bodija abattoir on the physicochemical parameters of Oshunkaye stream in Ibadan City, Nigeria," African Journal of Biotechnology, vol. 6, no. 15, pp. 1806-1811, 2007.

[4] W. E. Tekenah, P. I. Agi, and B. B. Babatunde, "Analysis of surface water pollution from abattoirs and the interrelationship between physico-chemical properties (A case study of the New Calabar River)," Journal of Environmental Science, Toxicology and Food Technology, vol. 8, no. 5, pp. 10-18, 2014.

[5] K. Al-Sabti and C. D. Metcalfe, "Fish micronuclei for assessing genotoxicity in water," Mutation Research, vol. 343, no. 2-3, pp. 121-135, 1995.

[6] A. Viarengo, D. Lowe, C. Bolognesi, E. Fabbri, and A. Koehler, "The use of biomarkers in biomonitoring: a 2-tier approach assessing the level of pollutant-induced stress syndrome in sentinel organisms," Comparative Biochemistry and Physiology C, vol. 146, no. 3, pp. 281-300, 2007.

[7] F. K. Ali, A. M. El-Shehawi, and M. A. Seehy, "Micronucleus test in fish genome: a sensitive monitor for aquatic pollution," African Journal of Biotechnology, vol. 7, no. 5, pp. 606-612, 2008.

[8] C. G. Alimba, J. K. Saliu, A. Adesanya, and A. A. Bakare, "Evaluation of genotoxicity of a municipal landfill leachate by micronucleus test using Clarias gariepinus," Research in Environment and Life Sciences, vol. 4, no. 1, pp. 1-6, 2011.

[9] A. A. Bakare, O. A. Alabi, A. M. Gbadebo, O. I. Ogunsuyi, and C. G. Alimba, "In vivo cytogenotoxicity and oxidative stress induced by electronic waste leachate and contaminated well water," Challenges, vol. 4, no. 2, pp. 169-187, 2013.

[10] S. O. Ayoola, B. O. Bassey, C. G. Alimba, and E. K. Ajani, “Textile effluent induced genotoxic effects and oxidative stress in Clarias gariepinus," Pakistan Journal of Biological Sciences, vol. 15, no. 17, pp. 804-812, 2012.
[11] N. K. Raheem and O. A. Morenikeji, "Impact of abattoir effluents on surface waters of the Alamuyo stream in Ibadan," Journal of Applied Sciences and Environmental Management, vol. 12, no. 1, pp. 73-77, 2008.

[12] American Public Health Association (APHA), Standard Methods for the Examination of Water and Wastewater, American Public Health Association (APHA), Washington, DC, USA, 20th edition, 2005.

[13] United State Environmental Protection Agency (USEPA), "Method 8270C revision 3, semi volatileorganic compounds by gas chromatography/mass spectrometry (GC/MS)," 1996, http://www.epa.gov/epaoswer/hazwaste/test/main.htm.

[14] E. O. Ajayi, Cytogenotoxicity of Bodija abattoir wastewater using induction of micronucleus and nuclear abnormalities in peripheral erythrocytes of Clarias gariepinus (Burchell, 1822) [M.S. thesis], Department of Zoology, University of Ibadan, Ibadan, Nigeria, 2015.

[15] P. J. Singh, S. Pandey, and S. Sharma, "Micronucleus assay for evaluation of in vivo genotoxicity in fishes: training on genotoxic assays in fishes," in TOGAIF-2005, D. Kapoor and N. S. Nagpure, Eds., pp. 1-107, National Bureau of Fish Genetic Resources, Uttar Pradesh, India, 2005.

[16] K. R. Carrasco, K. L. Tilbury, and M. S. Myers, "Assessment of the piscine micronucleus test as an in situ biological indicator of chemical contaminant effects," Canadian Journal of Fisheries and Aquatic Sciences, vol. 47, no. 11, pp. 2123-2136, 1990.

[17] G. S. Mittal, "Characterization of the effluent wastewater from abattoirs from landfill application," Food Reviews International, vol. 20, no. 3, pp. 229-256, 2004.

[18] D. O. Omole and E. O. Longe, "An assessment of the impact of abattoir effluents on River Illo, Ota, Nigeria," Journal of Environmental Science and Technology, vol. 1, no. 2, pp. 56-64, 2008.

[19] O. U. Ezeronye and A. O. Ubalua, "Studies on the effect of abattior and industrial effluents on the heavy metals and microbial quality of Aba river in Nigeria," African Journal of Biotechnology, vol. 4, no. 3, pp. 266-272, 2005.

[20] C. Russo, L. Rocco, M. A. Morescalchi, and V. Stingo, "Assessment of environmental stress by the micronucleus test and the Comet assay on the genome of teleost populations from two natural environments," Ecotoxicology and Environmental Safety, vol. 57, no. 2, pp. 168-174, 2004.

[21] B. Kurelec, “The genotoxic disease syndrome," Marine Environmental Research, vol. 35, no. 4, pp. 341-348, 1993.

[22] P. Bhattacharjee, M. Banerjee, and A. K. Giri, "Role of genomic instability in arsenic-induced carcinogenicity. A review," Environment International, vol. 53, pp. 29-40, 2013.

[23] P. Ghosh, M. Banerjee, S. De Chaudhuri et al., "Increased chromosome aberration frequencies in the Bowen's patients compared to non-cancerous skin lesions individuals exposed to arsenic," Mutation Research, vol. 632, no. 1-2, pp. 104-110, 2007.

[24] T.-S. Wang, T.-Y. Hsu, C.-H. Chung, A. S. S. Wang, D.-T. Bau, and K.-Y. Jan, "Arsenite induces oxidative DNA adducts and DNA-protein cross-links in mammalian cells," Free Radical Biology and Medicine, vol. 31, no. 3, pp. 321-330, 2001.

[25] I. Bremner, "Manifestations of copper excess," The American Journal of Clinical Nutrition, vol. 67, no. 5, pp. 1069S-1073S, 1998.

[26] R. Gabbianelli, G. Lupidi, M. Villarini, and G. Falcioni, "DNA damage induced by copper on erythrocytes of gilthead sea bream Sparus aurata and mollusk Scapharca inaequivalvis," Archives of Environmental Contamination and Toxicology, vol. 45, no. 3, pp. 350-356, 2003. 
[27] H. S. Unceer, S. Ayaz, O. Beyazoulu, and E. Senturk, "Cytogenetic effects of copper chloride on the root tip cells of Helianthus annuus L.," Turkish Journal Biology, vol. 27, pp. 43-46, 2003.

[28] O. Chukwu, P. A. Adeoye, and I. Chidiebere, "Abattoir wastes generation, management and the environment: a case of Minna, North Central Nigeria," International Journal of Biosciences, vol. 1, no. 6, pp. 100-109, 2011.

[29] S. Burney, J. L. Caulfield, J. C. Niles, J. S. Wishnok, and S. R. Tannenbaum, "The chemistry of DNA damage from nitric oxide and peroxynitrite," Mutation Research, vol. 424, no. 1-2, pp. 3749, 1999.

[30] N. R. Hooftman and W. K. de Raat, "Induction of nuclear abnormalities (micronuclei) in the peripheral blood erythrocytes of the eastern mudminnow Umbra pygmaea by ethyl methanesulphonate," Mutation Research, vol. 104, no. 1-3, pp. $147-152,1982$.

[31] B. de Campos Ventura, D. D. F. de Angelis, and M. A. MarinMorales, "Mutagenic and genotoxic effects of the Atrazine herbicide in Oreochromis niloticus (Perciformes, Cichlidae) detected by the micronuclei test and the comet assay," Pesticide Biochemistry and Physiology, vol. 90, no. 1, pp. 42-51, 2008.

[32] M. Fenech, W. P. Chang, M. Kirsch-Volders, N. Holland, S. Bonassi, and E. Zeiger, "Human micronucleus project (HUMN Project): detailed description of the scoring criteria for the cytokinesis-block micronucleus assay using isolated human lymphocyte cultures," Mutation Research, vol. 534, no. 1-2, pp. 65-75, 2003.

[33] V. Rodilla, "Origin and evolution of binucleated cells and binucleated cells with micronuclei in cisplatin-treated $\mathrm{CHO}$ cultures," Mutation Research, vol. 300, no. 3-4, pp. 281-291, 1993.

[34] D. Kligerman, "Fishes as biological detectors of the effect of genotoxic agents," in Mutagenicity: New Horizons in Genetic Toxicology, J. Heddle, Ed., pp. 87-93, Academic Press, New York, NY, USA, 1982.

[35] A. O. Adeogun, A. V. Chukwuka, and O. R. Ibor, "Impact of abattoir and saw-mill effluents on water quality of upper Ogun River (Abeokuta)," American Journal of Environmental Science, vol. 7, pp. 525-530, 2011.

[36] C. G. Alimba, J. K. Saliu, and O. A. Ubani-Rex, "Cytogenotoxicity and histopathological assessment of Lekki Lagoon and Ogun River in Synodontis clarias (Linnaeus, 1758)," Toxicological \& Environmental Chemistry, vol. 97, no. 2, pp. 221-234, 2015. 

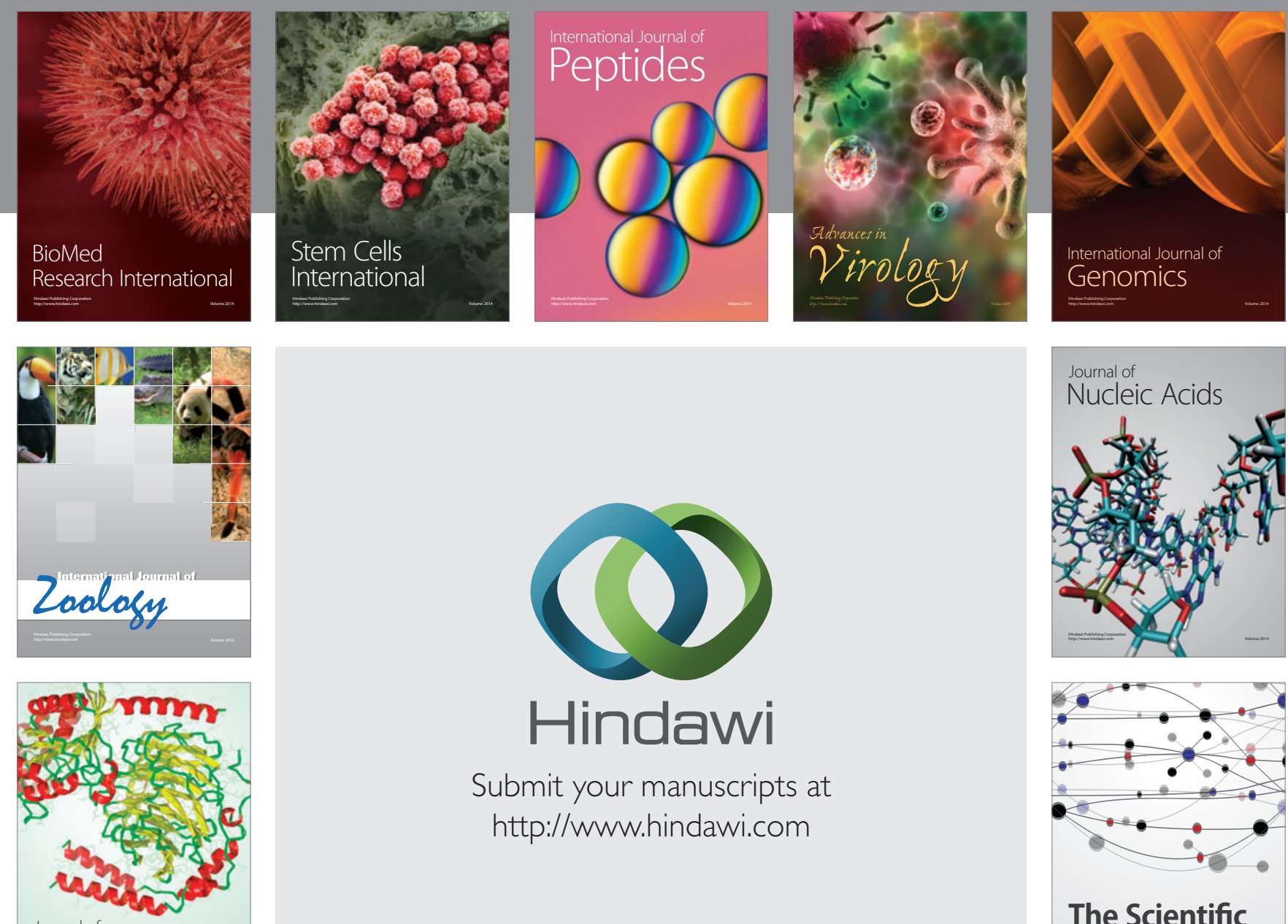

Submit your manuscripts at

http://www.hindawi.com

Journal of
Signal Transduction
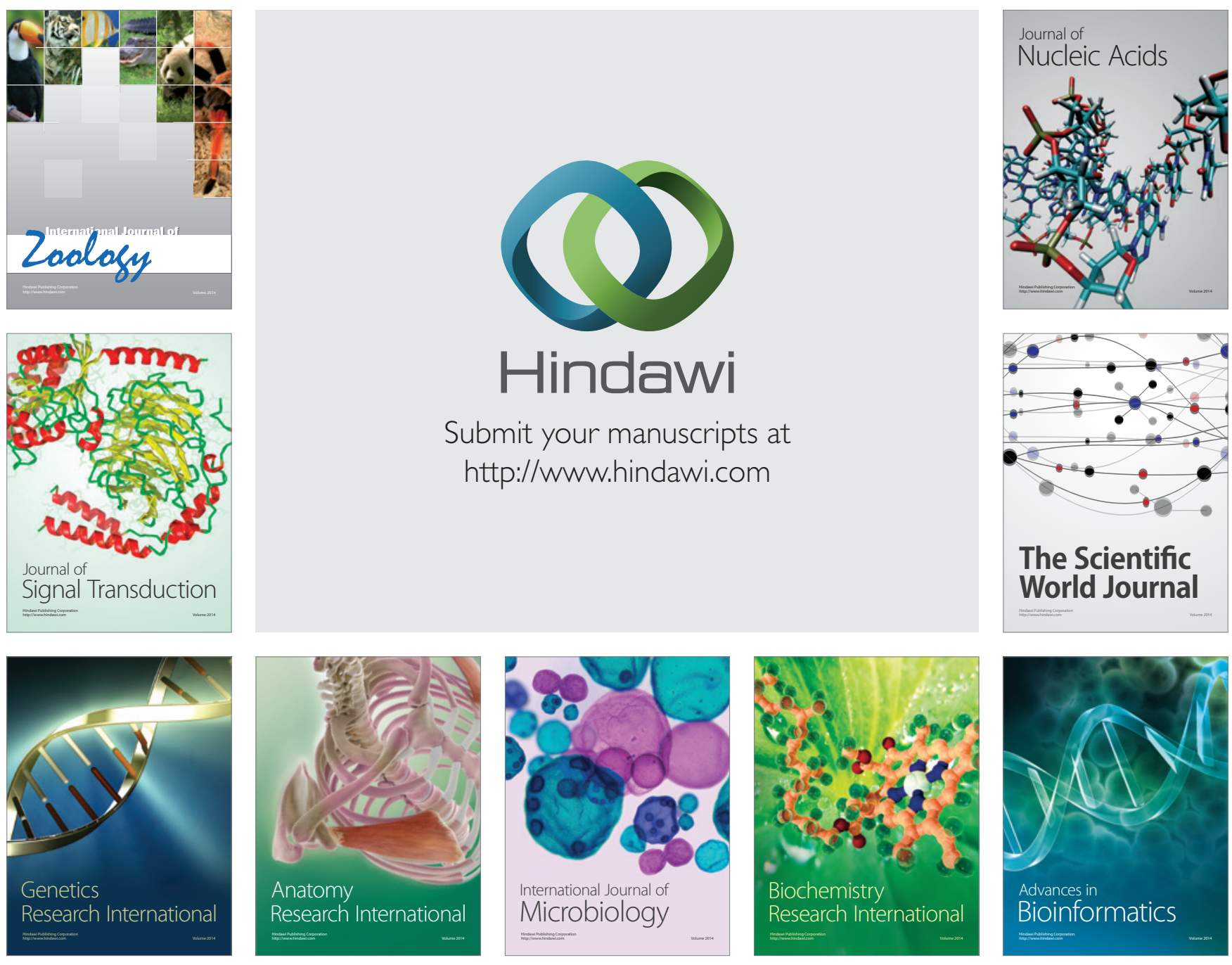

The Scientific World Journal
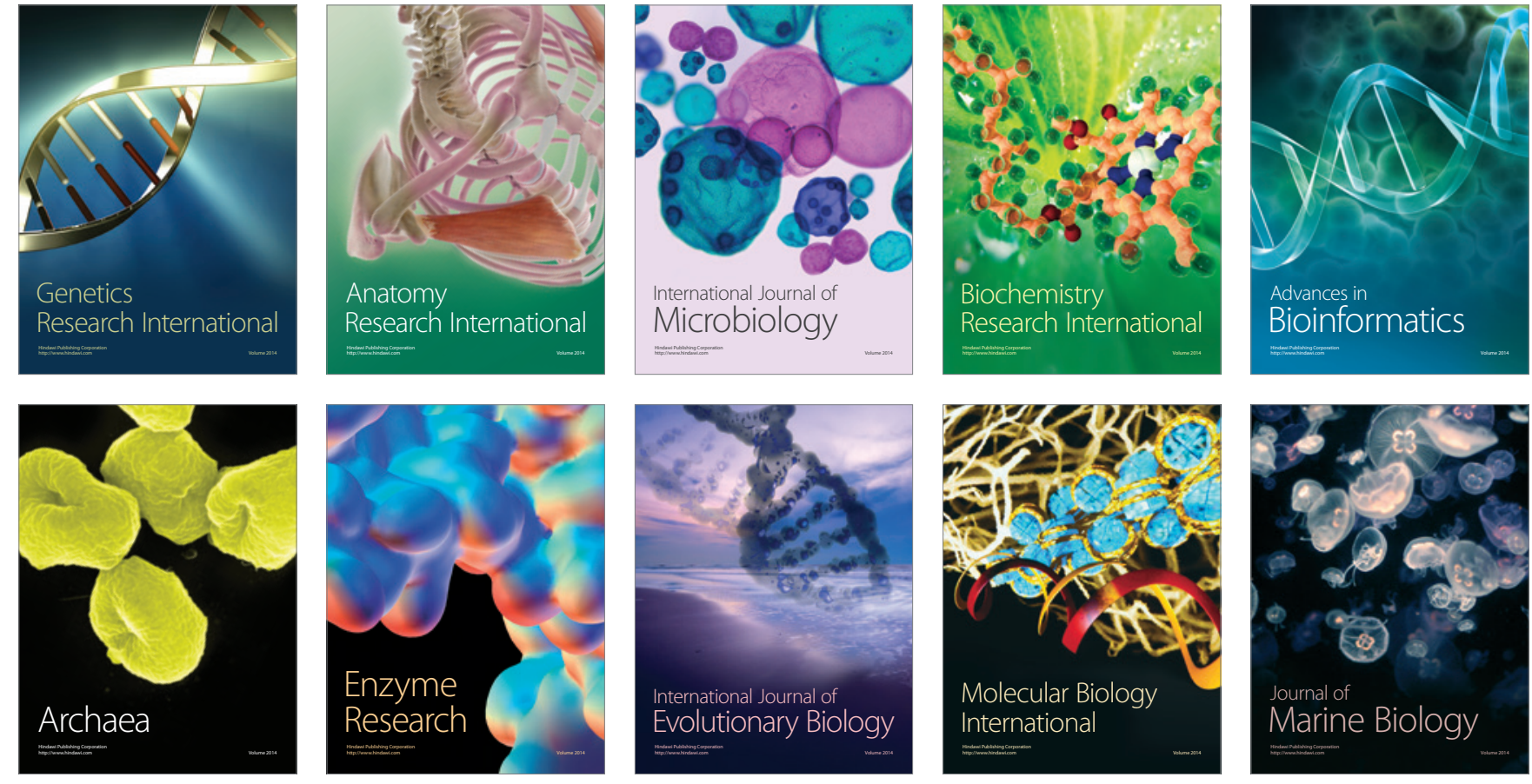